Kredo 4 (2020)
KREDO: Jurnal Ilmiah Bahasa dan Sastra
Terakreditasi Sinta 4 berdasarkan Keputusan Direktorat
Jenderal Penguatan Riset dan Pengembangan,
Kementerian Riset, Teknologi dan Pendidikan Tinggi
Republik Indonesia
Nomor: 23/E/KPT/2019. 08 Agustus 2019
https://jurnal.umk.ac.id/index.php/kredo/index

\title{
PENGEMBANGAN MEDIA AUDIO VISUAL DALAM PENGAJARAN MATA KULIAH MORFOLOGI INTEGRASI PENDIDIKAN BUDAYA DAN NILAI KARAKTER
}

\author{
Munirah $^{1}$, Sulfasyah $^{2}$, Muh. Dahlan ${ }^{3}$, Akram Budiman Yusuf $^{4}$ \\ munirah@unismuh.ac.id
}

Universitas Muhammadiyah Makassar, Indonesia

Info Artikel
Sejarah Artikel
Diterima
5 September 2020
Disetujui
10 September 2020
Dipublikasikan
28 Oktober 2020
Keywords
Audiovisual
Culture
Character Value
Indonesian
Morphology
Kata Kunci
Audio visual
Budaya
Nilai Karaker
Morfologi Bahasa
Indonesia

\begin{abstract}
This study aims to develop audio-visual learning media that is integrated with cultural education and character values, audio-visual learning in several learning concepts in morphology courses in higher education, lecturers' efforts to integrate the culture and character of the nation require a foundation of knowledge and skills. because the implementation of cultural and character education has been proclaimed by the government at all levels of education. This study aims to describe the procedure for developing audio visual media. This type of development research is based on the ADDIE model. The method used is a qualitative description. In the initial study, this research involved collaborative Indonesian morphology teaching partners to obtain information regarding the conditions of morphology learning. This research data collection technique was carried out through questionnaires, interviews and analysis of morphology teaching materials that were integrated with cultural education and character values. The results showed that the process of developing the use of audio visual media through the ADDIE development stage, namely analysis, design, development, implementation, and evaluation. The results of the validation test are very practical to use and the test is limited with an average response to the questionnaire response : $\quad$ from the aspect of material presentation of $88.95 \%$. Student response of $93.46 \%$ with the criteria "very practical".
\end{abstract}

\begin{abstract}
Abstrak
Penelitian ini bertujuan untuk mengembangkan media audio visual pembelajaran yang terintegrasi pendidikan budaya dan nilai karakter, pembelajaran audio visual dalam beberapa konsep pembelajaran mata kuliah morfologi yang ada di perguruan tinggi, upaya dosen untuk mengintegrasikan budaya dan karakter bangsa tersebut diperlukan landasan pengetahuan dan keterampilan yang dimiliki, sebab penerapan pendidikan budaya dan karakter telah dicanangkan oleh pemerintah di semua tingkat pendidikan. Penelitian ini bertujuan untuk mendeskripsikan prosedur pengembangan media audio visual. Jenis penelitian pengembangan berdasarkan model ADDIE. Metode yang gunakan adalah deskripsi kualitatif. Pada studi awal, penelitian ini melibatkan mitra kerjasama pengajar morfologi Bahasa Indonesia, untuk mendapatkan informasi terkait kondisi pembelajaran morfologi. Teknik pengumpulan data penelitian ini dilakukan melalui angket, wawancara dan analisis bahan ajar pembelajaran morfologi yang terintegrasi pendidikan budaya dan nilai karakter. Hasil penelitian menunjukkan bahwa proses pengembangan pemanfaatan media audio visual melalui tahap pengembangan ADDIE yaitu analysis, design, developmnet, implementation, and evaluation. Hasil uji validasi sangat praktis digunakan dan uji terbatas dengan respon rata hasil angket respons dosen dari segi aspek penyajian materi sebesar $88.95 \%$. Respon mahasiswa sebesar $93.46 \%$ dengan kriteria "sangat praktis".
\end{abstract}

\section{PENDAHULUAN}

Konstitusi dengan jelas menjabarkan tugas dan fungsi tenaga dosen sebagai perwalian tugas dan kewajiban negara yang diatur di dalam Undang-Undang Dasar Tahun 1945 Pasal 31 Ayat (3) bahwa pemerintah mengusahakan dan menyelenggarakan suatu Sistem Pendidikan Nasional yang meningkatkan keimanan dan ketakwaan serta akhlak mulia dalam rangka mencerdaskan kehidupan bangsa yang diatur dengan undang-undang. Selanjutnya, dipertegas di dalam Undang-Undang Sistem Pendidikan Nasional Nomor 20 Tahun 


\begin{tabular}{|c|c|c|}
\hline & $\begin{array}{c}\text { Kredo } 4(2020) \\
\text { KREDO: Jurnal Ilmiah Bahasa dan Sastra } \\
\text { Terakreditasi Sinta } 4 \text { berdasarkan Keputusan Direktorat } \\
\text { Jenderal Penguatan Riset dan Pengembangan, } \\
\text { Kementerian Riset, Teknologi dan Pendidikan Tinggi } \\
\text { Republik Indonesia } \\
\text { Nomor: 23/E/KPT/2019. 08 Agustus 2019 } \\
\text { https://jurnal.umk.ac.id/index.php/kredo/index }\end{array}$ & $\begin{array}{l}\mathrm{KREDO} \\
\square= \\
\square= \\
\square= \\
\square=\end{array}$ \\
\hline
\end{tabular}

2003 Pasal 40 Ayat (2a) bahwa tenaga kependidikan (dosen) berkewajiban memiliki komitmen secara profesional untuk meningkatkan mutu pendidikan (Handri, 2012). Jadi, tidak ada lagi alasan bagi tenaga pendidik khususnya dosen untuk tidak berpikir, berkegiatan, berkreasi, dan melahirkan inovasiinovasi terbaru dalam rangka menunaikan tugas dan tanggung jawab tersebut. Apa lagi, sekarang ini, Indonesia diperhadapkan pada era pembangunan berencana menuju peradaban bangsa yang berkemajuan guna memeroleh posisi yang strategis di dunia internasional.

Undang-Undang secara rinci menjelaskan petunjuk intruksional pelaksanaan kinerja profesional dosen, salah satu diantaranya pengembangan proses dan satuan pendidikan sebagaimana yang dijelaskan di dalam Undang-Undang Sistem Pendidikan Nasional Nomor 20 Tahun 2003 Pasal 39 Ayat (1) bahwa tenaga kependidikan bertugas untuk melaksanakan administrasi, pengelolaan, pengembangan, pengawasan, dan pelayanan teknis untuk menunjang proses dan satuan pendidikan. Seperti yang dikemukakan Cronje bahwa yang menjadi permasalahan adalah keadaan dosen atau tenaga pendidik yang tidak mengerti dan memahami dengan baik tugas dan fungsinya sebagaimana yang dijelaskan di dalam undang-undang tersebut (Cronjé, 2006).

Penelitian dan pengembangan media pembelajaran audio visual mata kuliah morfologi terintegrasi pendidikan budaya dan nilai pendidikan karakter ini didasari pada harapan dan kenyataan mengenai media pembelajaran yang sesuai dengan kebutuhan pembelajar, memenuhi standar proses, serta mendukung peningkatan hasil atau prestasi mahasiswa. Sebab, jika sebuah material pembelajaran dikembangkan sesuai dengan kebutuhan, memenuhi standar proses, serta berorientasi pada peningkatan kognitif, afektif, dan psikomotor pengguna tentunya akan memudahkan dalam pencapaian tujuan (Barab \& Luehmann, 2003).

Terkait dengan media pembelajaran audio visual, mahasiswa dan dosen menghendaki produk yang sesuai dengan kebutuhan belajar dan mengajar mereka. Bagi mahasiswa, tujuannya sederhana yaitu memudahkan mereka untuk belajar, memahami materi, memberikan kemudahan akses, menarik, mudah dimiliki, sehingga berdampak positif terhadap hasil atau prestasi belajarnya. Sedangkan bagi dosen, media pembelajaran yang baik mampu mempermudah proses pemberian materi sehingga harapan pencapaian proses dan tujuan pembelajaran dengan mudah terlaksana (Putra, 2011). Namun faktanya, media pembelajaran yang selama ini digunakan oleh dosen dalam proses perkuliahan belum sampai pada pemenuhan harapan tersebut, terutama untuk pengajaran mata kuliah morfologi yang selama dilaksanakan oleh dosen dan mahasiswa di Universitas Muhammadiyah Makassar. Terdapat kelemahan atau kekurangan baik dari segi materi, sistematika penyajian, tata grafik, bahasa, maupun media yang digunakan. Alasan peneliti mengatakan bahwa media pembelajaran yang selama ini digunakan belum memenuhi persyaratn ideal sebagaimana ketentuan bahwa bahan pembelajaran, terutama 


Kredo 4 (2020)
KREDO: Jurnal Ilmiah Bahasa dan Sastra
Terakreditasi Sinta 4 berdasarkan Keputusan Direktorat
Jenderal Penguatan Riset dan Pengembangan,
Kementerian Riset, Teknologi dan Pendidikan Tinggi
Republik Indonesia
Nomor: 23/E/KPT/2019. 08 Agustus 2019
https://jurnal.umk.ac.id/index.php/kredo/index

media pembelajaran yang selama ini banyak digunakan belum melalui serangkaian proses yang jelas, logis, sistematis, serta belum dilakukan uji coba (Putra, 2011). Bukankah Badan Standar Nasional Pendidikan (BSNP) telah memberikan batasan terkait bahan ajar yang layak pakai yaitu harus melalui serangkaian uji kelayakan agar memperoleh sintesis yang jelas dan ilmiah (Pendidikan, 2006). Mendukung fakta tersebut, hasil survei yang dilakukan peneliti terhadap kepuasan dan penilaian 100 mahasiswa Program Studi Pendidikan Bahasa dan Sastra Indonesia, Fakultas Keguruan dan Ilmu Pendidikan (FKIP), Universitas Muhammadiyah Makassar terhadap media pembelajaran yang digunakan menunjukkan $\quad 7 \%$ mahasiswa menyatakan cukup puas dan menilai media pembelajaran yang digunakan dalam pembelajaran cukup memadai, $83 \%$ mahasiswa menyatakan kurang puas dan menilai media pembelajaran yang digunakan dalam pembelajaran kurang memadai, serta $10 \%$ lainnya menyatakan ketidakpuasannya terhadap media pembelajaran karena selama proses pembelajaran media tersebut tidak memadai atau tidak sesuai harapan mahasiswa. Atas temuan inilah peneliti melakukan pengembangan media pembelajaran dalam bentuk audio visual untuk pengajaran mata kuliah morfologi. Menurut penelitian, media audio visual efektif terhadap pencapaian proses dan tujuan pembelajaran (Firdaus, 2016). Selain, media audio visual juga berpengaruh positif dan signifikan terhadap hasil belajar (Haryoko, 2012; Prasetia, 2016; Rifai, 2018).
Selain menaruh perhatian terhadap permasalahan media pembelajaran, peneliti juga menaruh perhatian yang serius terhadap masalah tumbuh kembang kepribadian mahasiswa menghadapi kemajuan era saat ini. (Smith, 2004) mengungkapkan bahwa semakin berkembangnya dimensi peradaban manusia, maka peluang degradasi moral pun akan semakin besar. Dalam hal ini, Smith memosisikan generasi muda (khususnya kalangan pelajar/mahasiswa) sebagai sasaran utama dari pendegredasian tersebut. Menurutnya, kemampuan generasi muda beradaptasi terhadap perubahan dan perkembangan zaman belum disertai dengan kemampuan untuk melindungi dirinya (defends mecanism) dari dampak yang ditimbulkan. Maka tidak heran jika sekarang ini di masyarakat khususnya kalangan generasi muda timbul berbagai masalah sosial yang terindikasi krisis moral, nilai karakter, dan krisis nilainilai budaya yang dahulunya dijunjung tinggi. Kondisi tersebut terjadi akibat melemahnya berbagai norma atau tata nilai yang selama ini menjadi falsafah kehidupan masayarakat, serta hilangnya kepedulian dan rasa memiliki dalam diri para generasi muda terhadap nilai budaya dan karakter itu sendiri (Susanti, 2016). Untuk itu, pendidikan budaya dan nilai moral atau karakter merupakan jawaban atas permasalahan tersebut sebagaimana yang dijelaskan oleh Wringe bahwa jawaban atas permasalahan karakter adalah pendidikan karakter (Wringe, 2006). Menurut Wringe, basis yang paling baik dalam pendidikan karakter adalah agama atau nilai-nilai sosial yang dijunjung tinggi dalam suatu komunitas tertentu. 


Kredo 4(2020)
KREDO: Jurnal Ilmiah Bahasa dan Sastra
Terakreditasi Sinta 4 berdasarkan Keputusan Direktorat
Jenderal Penguatan Riset dan Pengembangan,
Kementerian Riset, Teknologi dan Pendidikan Tinggi
Republik Indonesia
Nomor: 23/E/KPT/2019. 08 Agustus 2019
https://jurnal.umk.ac.id/index.php/kredo/index

Untuk itulah, pengembangan media pembelajaran audiovisual untuk mata kuliah morofologi diintegrasikan dengan pendidikan budaya dan nilai karakter.

\section{KAJIAN TEORI}

\section{Media Pembelajaran Audio Visual}

Pada hakikatnya media merupakan alat atau sarana untuk mencapai atau mentransfer sesuatu (Mahnun, 2012). Sedangkan media pembelajaran merupakan alat atau sarana yang digunakan sebagai perantara penyampai isi atau pesan-pesan pendidikan (Susilana \& Riyana, 2008). Media pembelajaran audio visual merupakan alat atau sarana perantara penyampai isi, materi atau pesan pembelajaran yang menggabungkan dua keinderaan dalam satu media yaitu aspek audio atau pendengaran dan visual atau penglihatan (Muhson, 2010). Media audia audio visual lebih efektif penggunaannya jika dibandingkan dengan media lainnya yang hanya berfokus pada satu keinderaan saja, sebab media ini memainkan dua keinderaan primer pada diri manusia yang menghubungkan langsung pada memori manusia yaitu pendengaran dan penglihatan (Firdaus, 2016; Haryoko, 2012; Prasetia, 2016; Purwono, 2014). Menentukan jenis media yang akan digunakan dalam pembelajaran menjadi sangat penting. Sebab, media adalah perpanjangan tangan atau fungsi kedua dari seorang pengajar dalam mentransfer ilmu pengetahuan. Oleh karena itu, meilih dan menerapkan media pembelajaran harus dengan memperhatikan karakter media, karakter materi, karakter lingkungan, dan karakter pengguna atau sasaran (Falahudin, 2014).

\section{Budaya}

Budaya merupakan alat yang mengatur manusia agar dapat memahami bagaimana ia berindak, berbuat dan menetukan sikapnya ketika mereka berinteraksi dengan yang lainnya (Pengertian Budaya, Unsur, Wujud \& Fungsi Menurut Para Ahli - serupa.id, n.d.). Budaya berasal dari bahasa asing yaitu culture yang berarti kebudayan, namun dalam bahasa Latin kata budaya adalah colere yang memiliki arti mengerjakan atau mengolah, yakni bertani atau mengolah tanah. Karya masyarakat menghasilkan teknologi dan kebudayaan kebendaan atau kebudayaan jasmaniah (material culture) yang diperlukan oleh manusia untuk menguasai alam sekitarnya, agar kekuatan serta hasilnya dapat diabdikan pada keperluan masyarakat (Anastasia and Sunahrowi, 2019).

Secara etimologis, istilah kearifan mengacu pada kemampuan seseorang untuk menanggapi peristiwa, benda atau situasi dengan pikirannya sendiri. Sedangkan kata lokal dimaknai sebagai suatu ruang yang dijadikan interaksi pada suatu situasi atau peristiwa terjadi. Maka dari itu, secara substansial kearifan lokal adalah nilai-nilai dan norma yang berlaku pada suatu masyarakat dan kebenarannya diyakini serta merupakan acuan dalam melakukan suatu tindakan dan perilaku sehari-hari (Patta Rapanna, 2016). Kearifan lokal dapat pula dikatakan sebagai suatu kemampuan untuk menyikapi dan memberdayakan berbagai potensi nilai luhur yang terdapat pada suatu budaya. 


\begin{tabular}{|c|c|c|}
\hline & $\begin{array}{c}\text { Kredo } 4(2020) \\
\text { KREDO: Jurnal Ilmiah Bahasa dan Sastra } \\
\text { Terakreditasi Sinta } 4 \text { berdasarkan Keputusan Direktorat } \\
\text { Jenderal Penguatan Riset dan Pengembangan, } \\
\text { Kementerian Riset, Teknologi dan Pendidikan Tinggi } \\
\text { Republik Indonesia } \\
\text { Nomor: 23/E/KPT/2019. 08 Agustus 2019 } \\
\text { https://jurnal.umk.ac.id/index.php/kredo/index }\end{array}$ & $\begin{array}{l}\mathrm{KREDO} \\
\square= \\
\square= \\
\square= \\
\square=\end{array}$ \\
\hline
\end{tabular}

Maka dari itu, kearifan lokal adalah suatu entitas yang menjadi penentu harkat dan martabat manusia di komunitas yang ia miliki (Kraidy and Murphy, 2008). Budaya dapat pula dikatakan sebagai suatu perilaku yang sifatnya umum dan berlaku secara turunmenurun dan meluas serta akan berkembang menjadi nilai-nilai yang dipegang teguh. Gobyah (2003) mendefenisikan kearifan lokal sebagai suatu kebenaran yang telah mendarah daging atau menyatu dalam suatu daerah. Local wisdom atau kearifan lokal juga diartikan sebagai usaha manusia dengan memakai akal budi yang dimiliki untuk bersikap dan bertindak pada sesuatu, objek bahkan peristiwa yang terjadi pada wilayah tertentu (Khusniati, 2014).

Unsur-unsur Pesenggiri Piil bukan hanya asas kosong, tetapi juga luhur nilai-nilai budaya nasionalis yang perlu dipahami dan dipraktikkan dalam kehidupan bermasyarakat dan berbangsa. Faktanya, ekspresi Piil Pesenggiri bukanlah mengorbankan orang lain dengan mengorbankan dirinya, atau dengan menghormati seseorang yang jauh lebih tinggi dari dirinya, atau dengan menyiksa orang lain untuk membuat seseorang bahagia (Juwita, Cahyono, and Jazuli, 2017). Orang yang memiliki harga diri akan lebih bersemangat, lebih mandiri, lebih mampu, lebih mampu, mampu menerima tantangan, lebih percaya diri, tidak mudah menyerah dan menyerah, mudah bertanggung jawab, dapat menghadapi kehidupan dengan lebih baik dan merasa setara dengan orang lain.

266 | Jurnal Kredo Vol. 4 No. 1 Oktober 2020

\section{Pendidikan Karakter}

Muttaqin (2012) menyatakan bahwa pada jenjang pendidikan formal yang menjadi basis pengembangan karakter adalah siswa. Pendidikan karakter di sekolah dasar merupakan kebutuhan vital agar generasi penerus dapat dibekali dengan kemampuan dasar yang tidak saja mampu menjadikannya lifelong learners sebagai salah satu karakter penting untuk hidup di era informasi yang bersifat global, tetapi juga mampu berfungsi dengan peran serta yang positif baik sebagai pribadi,sebagai anggota keluarga, warga negara, maupun warga dunia. Untuk itu harus dilakukan upayaupaya instrumental untuk meningkatkan keefektifan proses pembelajaran disertai pengembangan kultur yang positif.

Karakter yang baik mencakup pengertian, kepedulian dan tindakan yang sesuai dengan nilai-nilai etika (Bashori, 2010). Oleh karena itu, pendekatan pengembangan karakter yang komprehensif bertujuan untuk mengembangkan aspek kognitif, emosional dan perilaku kehidupan moral. Melalui pembelajaran, diskusi, observasi model perilaku dan pemecahan masalah termasuk nilai, siswa dapat memahami nilai inti. Oleh karena itu, siswa harus memahami nilai-nilai inti dan berkomitmen untuk mempraktikkannya dalam kehidupan sehari-hari.

\section{Morfologi Bahasa Indonesia}

Secara etimologis, morfologi adalah studi tentang kerumitan bentuk kata. Dalam bentuk kata makan, makan, makan dan makan, hati memiliki fungsi yang berbeda-beda. Pada kata makan berfungsi sebagai akar kata, makanan 


\begin{tabular}{|c|c|} 
Kredo 4 (2020) \\
KREDO: Jurnal Ilmiah Bahasa dan Sastra \\
Terakreditasi Sinta 4 berdasarkan Keputusan Direktorat \\
Jenderal Penguatan Riset dan Pengembangan, \\
Kementerian Riset, Teknologi dan Pendidikan Tinggi \\
Republik Indonesia \\
Nomor: 23/E/KPT/2019. 08 Agustus 2019 \\
https://jurnal.umk.ac.id/index.php/kredo/index
\end{tabular}

sebagai kata dengan sufiks, makanan sebagai pengulangan, dan makanan jantung sebagai kata majemuk (Suparno, 2015).

Menurut Ramlan (1981), morfologi merupakan bagian dari ilmu linguistik yang membahas atau mempelajari rahasia bentuk kata dan pengaruh perubahan bentuk kata tersebut terhadap kelompok dan makna kata. Dengan kata lain, morfologi mempelajari seluk beluk kata dan fungsi perubahan bentuk kata, baik fungsi gramatikal maupun semantik.

Perubahan bentuk kata menyebabkan perubahan kelas dan arti kata. Kata "kelas sepeda" tidak sama dengan "kelas sepeda". Kata sepeda termasuk ke dalam kelompok kata nominal sedangkan kata sepeda termasuk ke dalam kelompok kata. Sama halnya dengan kata rumah dan rumah. Kata house termasuk ke dalam kategori nominal kata berumah, termasuk kelompok kata verbal.

Menurut Basaria (2004) morfologi merupakan bagian dari tata bahasa yang menceritakan tentang bentuk kata. Tidaklah jelas untuk memahami bentuk kata jika kita tidak tahu lebih banyak tentang bentuknya dan seperti apa ciricirinya.

Dalam penelitian ini, media audio visual yang akan diteliti adalah media berbasis teknologi yang merepresentasikan elemen gambar dan suara sebagai alternatif penyajian objek tertentu untuk mendukung proses pembelajaran yang efektif dan praktis. Media audio visual memberikan banyak rangsangan kepada peserta didik karena sifat audio visual/suara-gambar (Purwono, 2014). Audio visual memperkaya lingkungan belajar, mendorong eksplorasi, eksperimen dan penemuan, serta mendorong siswa untuk mengembangkan kemampuan berbicara dan mengekspresikan pemikiran mereka.

\section{METODE PENELITIAN}

Jenis penelitian ini adalah Research and Development (R\&D). Prosedur pengembangan dan penelitian dalam model ADDIE meliputi analisis (analysis), desain (design), pengembangan (development), implementasi (implementation), dan evaluasi (evaluation) (Tegeh and Kirna, 2013). Lima tahapan proses pengembangan model ADDIE dapat dilihat pada bagan tahapan pengembangan, seperti pada gambar di bawah ini:

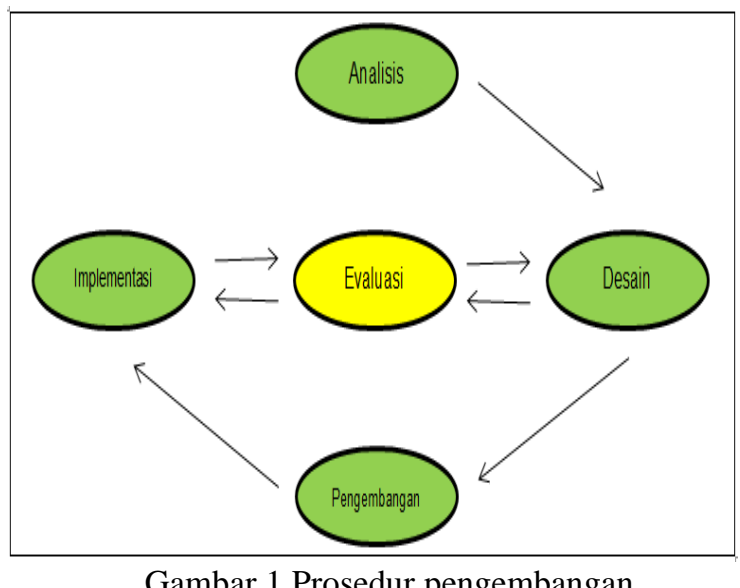

Gambar 1 Prosedur pengembangan

Langkah analisis, langkah ini terdiri dari; a) melakukan analisis kompetensi yang dibutuhkan dari siswa; b) menganalisis karakteristik siswa ditinjau dari kemampuan belajar, pengetahuan, keterampilan, sikap, dan aspek terkait lainnya; c) melakukan analisis materi sesuai dengan persyaratan kompetensi. 


Kredo 4 (2020)
KREDO: Jurnal Ilmiah Bahasa dan Sastra
Terakreditasi Sinta 4 berdasarkan Keputusan Direktorat
Jenderal Penguatan Riset dan Pengembangan,
Kementerian Riset, Teknologi dan Pendidikan Tinggi
Republik Indonesia
Nomor: 23/E/KPT/2019. 08 Agustus 2019
https://jurnal.umk.ac.id/index.php/kredo/index

Tahap desain dilakukan dalam kerangka acuan sebagai berikut: a) untuk siapa pembelajaran itu ditujukan (siswa); b) kemampuan yang ingin Anda pelajari (kompetensi); c) bagaimana mempelajari subjek atau keterampilan dengan baik (strategi pembelajaran); d) cara menentukan tingkat penguasaan materi yang telah dipelajari. Tahap pengembangan meliputi kegiatan pengumpulan materi edukasi multimedia interaktif, pembuatan ilustrasi, skrip dan lainnya. Aktivitas dalam tahap implementasi. Hasil pengembangan digunakan dalam pembelajaran untuk mengetahui dampaknya terhadap kualitas pembelajaran, termasuk efektivitas, daya tarik, dan efisiensi pembelajaran. Fase penilaian meliputi penilaian formatif dan penilaian sumatif.

Tingkat validitas media pembelajaran diketahui melalui hasil analisis kegiatan uji coba yang dilaksanakan melalui tahap review para ahli.

Data dalam penelitian ini meliputi proses pembelajaran morfologi, penggunaan media audio visual dalam pembelajaran morfologi, dan status siswa dalam pembelajaran morfologi. Sumber data yang dijadikan sasaran pengumpulan data antara lain informan yaitu mahasiswa dan dosen, serta kegiatan proses pembelajaran mahasiswa FKIP Unismuh.

Instrumen yang digunakan untuk mengumpulkan data dalam pengembangan ini adalah observasi, dokumentasi, angket, dan wawancara. Analisis data dalam penelitian ini menggunakan teknik analisis statistik deskriptif kuantitatif dan analisis data kualitatif.

\section{HASIL DAN PEMBAHASAN}

\section{Tahap Analisis}

Penelitian dan pengembangan ini diawali dengan tahap analisis yang meliputi analisis kebutuhan mahasiswa, analisis kurikulum, analisis perangkat lunak dan perangkat keras. Adapun data hasil analisis adalah sebagai berikut.

\section{Analisis Kebutuhan Mahasiswa}

Berdasarkan analisis kebutuhan mahasiswa diketahui bahwa siswa kurang antusias mempelajari morfologi bahasa Indonesia, mahasiswa mengalami kesulitan pada materi pembelajaran dari buku teks / resep morfologi, dan siswa tidak memiliki bahan ajar alternatif yang dapat digunakan untuk mempelajari morfologi bahasa Indonesia dengan mudah dan menarik. Mahasiswa menginginkan bahan ajar praktis yang dapat digunakan dimana saja, kapan saja. Mahasiswa saat ini hidup di dunia digital dan asli, sebagian besar mahasiswa sudah memiliki smartphone untuk diintegrasikan dengan media audiovisual. Khususnya dalam kasus IIA, 97,54\% siswa memiliki smartphone.

\section{Analisis Kurikulum}

Analisis kurikulum dilakukan dengan menyelaraskan proyek pengembangan media audiovisual dengan kurikulum yang digunakan pada kelas IIA Pengajaran Bahasa dan Sastra Indonesia. Data yang diperoleh berupa RPS yang meliputi hasil belajar, materi dan soal latihan yang berkaitan dengan pembelajaran bahasa Indonesia. RPS merupakan pedoman untuk mengumpulkan materi dan sumber pendidikan yang akan dimasukkan ke 


\begin{tabular}{|c|c|c|}
\hline & $\begin{array}{c}\text { Kredo } 4(2020) \\
\text { KREDO: Jurnal Ilmiah Bahasa dan Sastra } \\
\text { Terakreditasi Sinta } 4 \text { berdasarkan Keputusan Direktorat } \\
\text { Jenderal Penguatan Riset dan Pengembangan, } \\
\text { Kementerian Riset, Teknologi dan Pendidikan Tinggi } \\
\text { Republik Indonesia } \\
\text { Nomor: 23/E/KPT/2019. 08 Agustus 2019 } \\
\text { https://jurnal.umk.ac.id/index.php/kredo/index }\end{array}$ & $\begin{array}{l}\mathrm{KREDO} \\
\square= \\
\square= \\
\square= \\
\square=\end{array}$ \\
\hline
\end{tabular}

dalam media pendidikan berupa media audiovisual. Kemudian peneliti menganalisis materi tentang indikator pencapaian kompetensi di RPS. Setelah peneliti menganalisis kurikulum, ternyata materi morfologi hanya berupa konsep dan contoh yang kurang kontekstual. Setiap perkuliahan mencakup berbagai kegiatan. Kegiatan tersebut akan terlaksana dengan baik dan bermanfaat, jika dilakukan dengan menggunakan prosedur yang tepat. Pembelajaran morfologi BI menuntut siswa untuk terbiasa dengan konsep morfologi, morfem, proses morfofonik, reduplikasi, kata majemuk dan membedakan jenis kelas kata dari materi teks. Dengan mempelajari morfologi, siswa dapat memahami konsep morfologi dalam melakukan sesuatu dengan benar dan memberikan pemahaman kepada orang lain. Bentuk penyajian materi morfologi dapat dirancang dalam bentuk teks, audiovisual dan kuis interaktif.

\section{Analisis Perangkat}

Pembuatan media audio visiual morfologi bahasa Indonesia memerlukan naskah audio visual yang sesuai. Kamera/ HP yang digunakan untuk pembuatan media audio visual dengan berbentuk $\mathrm{CD} /$ youtube.

\section{Tahap Desain}

Tahap desain didasarkan pada halhal yang diperoleh dari tahap analisis. Pada tahap design, peneliti merancang konsep produk baru di atas kertas. Merancang alat baru untuk pengembangan produk. Proyek ini ditulis untuk setiap unit pengajaran. Instruksi terperinci mengimplementasikan proyek atau membuat produk. Kegiatan pada tahap perencanaan antara lain: merancang naskah audiovisual kemudian membuat media audiovisual. Tahap awal perancangan media audio. Pada bagian awal proyek perancangan media audiovisual dilakukan kegiatan yang meliputi pemilihan bahan, pemilihan objek, pembuatan naskah audiovisual, pembuatan bahan audiovisual dan editing media dilakukan.

\section{Pembuatan Instrumen Kelayakan}

Pada tahap mengeksekusi instrumen kelayakan, instrumen dilakukan atas dasar kisi instrumen yang dimodifikasi. Instrumen uji kelayakan dalam studi pengembangan ini terdiri dari Alat Validasi Ahli Media, Instrumen Validasi Ahli Materi, Instrumen Respon Dosen, Instrumen Respon Mahasiswa. Dalam uji validitas ini, ahli media akan menilai kualitas buku teks yang dihasilkan. Pembuatan dan pengembangan kuesioner didasarkan pada aspek-aspek berikut: (1) tampilan desain layar, (2) mudah digunakan, (3) konsistensi, (4) format, (5) kepraktisan, grafik.

\section{Tahap Pengembangan (Development)}

Tahap pengembangan ini merupakan tahap pengembangan produk berdasarkan desain yang telah ditentukan, dan desain tersebut akan diolah menjadi media audiovisual bergaya Indonesia. Uraian tahap pengembangan meliputi identifikasi materi budaya, penyusunan naskah audio visual, identifikasi objek, pembuatan media audio visual dan media edit. 


Kredo 4 (2020)
KREDO: Jurnal Ilmiah Bahasa dan Sastra
Terakreditasi Sinta 4 berdasarkan Keputusan Direktorat
Jenderal Penguatan Riset dan Pengembangan,
Kementerian Riset, Teknologi dan Pendidikan Tinggi
Republik Indonesia
Nomor: 23/E/KPT/2019. 08 Agustus 2019
https://jurnal.umk.ac.id/index.php/kredo/index

\section{Validasi Media}

Validasi media dilakukan oleh ahli media yaitu Muhammad Nasir, M.Pd. Ia adalah dosen Pendidikan Teknologi Pendidikan di Unismuh Makassar. Validasi ahli media ini bertujuan untuk mengetahui kelayakan audio visual ditinjau dari media yang dikembangkan. Untuk validasi media, penilaiannya meliputi (1) desain tampilan, (2) kemudahan penggunaan, (3) konsistensi, (4) format, (5) kegunaan, (6) grafik. Berikut adalah data yang diperoleh dari hasil validasi media.

Tabel 1 Hasil validasi ahli media

\begin{tabular}{|c|l|l|}
\hline No & \multicolumn{1}{|c|}{ Aspek } & Nilai \\
\hline 1 & Standar pemilihan ukuran huruf sudah sesuai & 5 \\
\hline 2 & Kesesuaian standar pemilihan jenis huruf & 5 \\
\hline 3 & $\begin{array}{l}\text { Ketepatan komposisi warna tulisan dengan warna } \\
\text { latar }\end{array}$ & 5 \\
\hline 4 & $\begin{array}{l}\text { Sistematika penyajian materi dalam modul } \\
\text { sekuensial }\end{array}$ & 5 \\
\hline 5 & Operasi audiovisual sederhana & 5 \\
\hline 6 & Instruksi untuk menggunakan program ini jelas & 4 \\
\hline 7 & Instruksi audiovisual tidak akan membingungkan & 5 \\
\hline 8 & Tombol layar penuh berfungsi dengan baik & 5 \\
\hline 9 & $\begin{array}{l}\text { Penggunaan kata, istilah, dan kalimat yang } \\
\text { konsisten }\end{array}$ & 5 \\
\hline 10 & Bentuk dan huruf digunakan yang konsisten & 5 \\
\hline 11 & Tata letak tampilan yang konsisten & 5 \\
\hline 12 & Tata letak tombol dan akurasi penulisan & 5 \\
\hline 13 & $\begin{array}{l}\text { Halaman media tidak akan membingungkan } \\
\text { pengguna }\end{array}$ & $\mathbf{4}$ \\
\hline 14 & $\begin{array}{l}\text { Audiovisual memudahkan siswa dalam menerima } \\
\text { materi yang diajarkan }\end{array}$ & 5 \\
\hline 15 & $\begin{array}{l}\text { Penggunaan audiovisual dapat meningkatkan } \\
\text { perhatian siswa terhadap materi pembelajaran }\end{array}$ & $\mathbf{4}$ \\
\hline 16 & $\begin{array}{l}\text { Penggunaan audiovisual menyederhanakan proses } \\
\text { pengajaran }\end{array}$ & 5 \\
\hline 17 & $\begin{array}{l}\text { Warna yang digunakan dalam audiovisual sudah } \\
\text { sesuai }\end{array}$ & 5 \\
\hline 18 & $\begin{array}{l}\text { Ukuran font yang digunakan dalam audiovisual } \\
\text { terlihat jelas }\end{array}$ & 5 \\
\hline
\end{tabular}

\begin{tabular}{|l|l|l|}
\hline 19 & $\begin{array}{l}\text { Font yang digunakan dalam audiovisual mudah } \\
\text { dibaca }\end{array}$ & 4 \\
\hline 20 & $\begin{array}{l}\text { Gambar yang digunakan memudahkan siswa } \\
\text { dalam memahami isi materi pembelajaran }\end{array}$ & 5 \\
\hline Skor total & 101 \\
\hline Skor ideal & 105 \\
\hline Persentase validitas & $\begin{array}{c}96,19 \\
\%\end{array}$ \\
\hline Kriteria & $\begin{array}{c}\text { Sangat } \\
\text { Valid }\end{array}$ \\
\hline
\end{tabular}

Uji coba terbatas yaitu dengan mengujicobakan audio visual kepada pengguna setelah dinyatakan valid oleh Ahli Media. Uji coba terbatas dilakukan pada 2 orang dosen morfologi bahasa Indonesia yaitu Akram Budiman Yusuf, S.Pd., M. Pd. dan Muhammad Imran, S. S., M.Hum. dilanjutkan dengan uji coba pembelajaran kepada 40 orang mahasiswa.

Uji coba diawali dengan penjelasan cara pemanfaatan kepada dosen morfologi bahasa Indonesia sebagai model uji coba. Guru diarahkan untuk mempelajari materi yang ada pada audio visual, mengerjakan uji materi dan uji kompetensi yang disediakan pada audio visual. Selanjutnya, dosen diberikan angket berupa formulir daring untuk mengetahui tanggapan tentang kepraktisan audio visual yang dikembangkan. Adapun data hasil uji coba pada dosen sebagai berikut.

Tabel 2 Rangkuman hasil uji coba

\begin{tabular}{|c|c|c|c|c|c|}
\hline \multirow[b]{2}{*}{ No } & \multirow[b]{2}{*}{ Aspek } & \multicolumn{2}{|c|}{ Responden } & \multirow{2}{*}{$\begin{array}{c}\text { Rata-rata } \\
\text { persentase } \\
\text { aspek }\end{array}$} & \multirow[b]{2}{*}{ Kriteria } \\
\hline & & I & II & & \\
\hline 1 & $\begin{array}{l}\text { Penyajian } \\
\text { Materi }\end{array}$ & 90,50 & 90,00 & 90,25 & $\begin{array}{l}\text { Sangat } \\
\text { praktis }\end{array}$ \\
\hline 2 & $\begin{array}{l}\text { Tampilan } \\
\text { Media }\end{array}$ & 90,00 & 90,00 & 90,00 & $\begin{array}{l}\text { Sangat } \\
\text { praktis }\end{array}$ \\
\hline 3 & $\begin{array}{l}\text { Penggunaan } \\
\text { Media }\end{array}$ & 83,30 & 90,00 & 86,60 & $\begin{array}{l}\text { Sangat } \\
\text { praktis }\end{array}$ \\
\hline \multicolumn{4}{|c|}{ Rata-rata total } & 88,95 & $\begin{array}{l}\text { Sangat } \\
\text { praktis }\end{array}$ \\
\hline
\end{tabular}




\begin{tabular}{|c|c|} 
Kredo 4 (2020) \\
KREDO: Jurnal Ilmiah Bahasa dan Sastra \\
Terakreditasi Sinta 4 berdasarkan Keputusan Direktorat \\
Jenderal Penguatan Riset dan Pengembangan, \\
Kementerian Riset, Teknologi dan Pendidikan Tinggi \\
Republik Indonesia \\
Nomor: 23/E/KPT/2019. 08 Agustus 2019 \\
https://jurnal.umk.ac.id/index.php/kredo/index
\end{tabular}

Hasil rata-rata survei angket dosen pengantar materi adalah 88,95\%. Artinya dosen memberikan respon yang sangat positif yaitu penyajian materinya jelas. Sebanyak $90.00 \%$ presentasi media menunjukkan bahwa karena daya tarik penyajian audiovisual, pembicara memberikan respon yang sangat positif. Persentase penggunaan media sebesar $86,60 \%$ yang menunjukkan bahwa dosen telah memberikan respon yang positif, karena audiovisual yang mudah digunakan, dapat meningkatkan pemahaman mahasiswa, mendorong kemandirian mahasiswa dan meningkatkan motivasi mahasiswa. Berdasarkan standar "sangat praktis", persentase rata-rata dari total tanggapan dosen adalah 88,90\%, dan kesimpulannya adalah audiovisual aktual digunakan sebagai bahan ajar dalam bentuk bahasa Indonesia di PBSI.

Uji coba terbatas juga dilakukan pada 40 mahasiswa semester II untuk mengetahui kepraktisan penggunaan media audio visual berdasarkan aspek (1) tampilan, (2) penyajian materi, (3) fungsi media jika diterapkan dalam kegiatan pembelajaran. Adapun data hasil uji coba, Rata hasil angket respons mahasiswa dari segi aspek tampilan sebesar $94.25 \%$. Aspek penyajian materi sebesar $93.88 \%$ menunjukkan peserta didik memberikan respons sangat positif karena penyajian materi media audio visual jelas. Aspek fungsi media media sebesar 92,25\% menunjukkan peserta didik memberikan respons positif karena media audio visual mampu memotivasi mahasiswa, mendorong keaktifan dan kemandirian mahasiswa serta memfasilitasi mahasiswa untuk belajar di mana saja, kapan saja. Hasil persentase rata-rata total respons mahasiswa sebesar $93,46 \%$ dengan kriteria "Sangat Praktis".

\section{Tahap Evaluasi (Evaluation)}

Tahap ini merupakan tahapan terakhir dalam proses pengembangan media audio visual yaitu melakukan proses hasil analisis data yang telah diperoleh pada saat implementasi.

Dari hasil analisis data, produk yang dikembangkan mudah dijalankan oleh mahasiswa. media audio visual yang dikembangkan menciptakan pengalaman belajar yang baru bagi peserta didik. Peserta didik dapat belajar sesuai dengan kecepatan belajarnya, di mana saja dan kapan saja. Guru dan peserta didik memberikan respons positif terhadap produk yang dikembangkan.

Berdasarkan hasil respons guru dan siswa, tidak ada saran perbaikan baik dari segi materi atau konten media sehingga peneliti tidak melakukan revisi dan produk yang dikembangkan dinyatakan produk akhir. Secara umum, kesan yang diperoleh dari mahasiswa adalah adanya ketertarikan terhadap media yang menarik. Mahasiswa juga lebih termotivasi karena mendapatkan pengalaman yang berbeda dalam belajar morfologi bahasa Indonesia. Media audio visual membantu peserta didik belajar kapan saja dan di mana saja.

Berdasarkan hasil validasi ahli media, audio visual mendapat tanggapan positif dari validator dengan jumlah keseluruhan jawaban dalam seluruh item sebanyak 101 dari 105 nilai ideal yang ditetapkan. Persentase validitas audio visual sebesar 96,19\% dengan kriteria "Sangat Valid" maka, audio visual 


Kredo 4(2020)
KREDO: Jurnal Ilmiah Bahasa dan Sastra
Terakreditasi Sinta 4 berdasarkan Keputusan Direktorat
Jenderal Penguatan Riset dan Pengembangan,
Kementerian Riset, Teknologi dan Pendidikan Tinggi
Republik Indonesia
Nomor: 23/E/KPT/2019. 08 Agustus 2019
https://jurnal.umk.ac.id/index.php/kredo/index

dinyatakan valid untuk digunakan sebagai bahan ajar.

Prosedur pengembangan media audio visual pengajaran morfologi bahasa Indonesia integrasi pendidikan budaya dan nilai karakter pada Prodi Pendidikan Bahasa dan Sastra Indonesia. Media audio visual dikembangkan dengan menggunakan perangkat lunak kamera /HP. Media audio visual morfologi Bahasa Indonesia integrasi pendidikan budaya dan nilai karakter dapat dimanfaatkan dalam proses belajar mengajar dan memfasilitasi mahasiswa untuk belajar di mana saja, kapan saja. Pengembangan media audio visual melalui tahap pengembangan ADDIE yaitu analysis, design, developmnet, implementation, and evaluation (Tegeh and Kirna, 2013). Tahap pertama pengembangan yaitu tahap analisis yang meliputi analisis kebutuhan mahasiswa, analisis kurikulum, analisis perangkat lunak dan perangkat keras.

Analisis kebutuhan mahasiswa meliputi pemikiran tentang produk bahan ajar/sumber belajar yang berupa media audio visual yang akan dikembangkan. Mengidentifikasi produk yang sesuai dengan sasaran mahasiswa, tujuan belajar, mengidentifikasi lingkungan belajar dan strategi penyampaian dalam pembelajaran. Berdasarkan analisis kebutuhan mahasiswa diketahui bahwa mahasiswa tidak antusias mempelajari morfologi bahasa Indonesia, mahasiswa kesulitan mempelajari materi dari buku paket dan peserta didik belum memiliki bahan ajar alternatif yang dapat digunakan untuk mempelajari morfologi bahasa Indonesia dengan mudah dan menarik. Mahasiswa menginginkan bahan ajar yang praktis agar dapat digunakan di mana pun dan kapan pun.

Analisis kurikulum dilakukan dengan cara menyesuaikan rancangan pengembangan bahan ajar dengan kurikulum yang digunakan pada PBSI Unismuh Makassar. Setelah peneliti melakukan analisis kurikulum, diperoleh informasi bahwa materi morfologi cocok untuk diintegrasikan contoh budaya Bugis Makassar yang berupa video pembelajaran karena contoh materi budaya dapat diterapkan dalam pembelajaran untuk melestarikan budaya Bugis Makassar. Aktivitas tersebut akan terlaksana dengan baik dan bermanfaat jika dilakukan dengan prosedur yang tepat. Dalam pembelajaran morfologi bahasa Indonesia, mahasiswa dituntut untuk menentukan dan merumuskan kaidah morfologi yang terintegrasi dengan pendidikan budaya dan nilai karakter. Dengan mempelajari teks prosedur, peserta didik dapat memahami prosedur melakukan sesuatu dengan benar dan memberikan pemahaman kepada orang lain. Bentuk penyajian materi teks prosedur dapat dirancang dalam bentuk aktivitas mahasiswa dengan mengamati teks, audio visual dan kuis yang interaktif.

Analisis perangkat lunak dan perangkat keras dilakukan dengan menentukan software dan hardware yang akan digunakan dalam pengembangan media audio visual morfologi bahasa Indonesia. Pembuatan audio visual dengan durasi 30 menit.

Pada tahap perancangan, peneliti merancang konsep produk baru di atas kertas. Rancangan ditulis untuk masingmasing unit pembelajaran. Petunjuk penerapan desain atau pembuatan 


Kredo 4 (2020)
KREDO: Jurnal Ilmiah Bahasa dan Sastra
Terakreditasi Sinta 4 berdasarkan Keputusan Direktorat
Jenderal Penguatan Riset dan Pengembangan,
Kementerian Riset, Teknologi dan Pendidikan Tinggi
Republik Indonesia
Nomor: 23/E/KPT/2019. 08 Agustus 2019
https://jurnal.umk.ac.id/index.php/kredo/index

produk ditulis secara rinci. Kegiatan yang dilakukan pada tahap perencanaan meliputi: perancangan naskah audio visual, perancangan alur (storyboard), rancangan desain awal media audio visual, dan pembuatan instrumen kelayakan.

Tahapan pengembangan produk sesuai dengan rancangan yang sudah ditentukan sebelumnya untuk diproses menjadi media audiao visual morfologi bahasa Indonesia integrasi pendidikan budaya dan nilai karakter, meliputi: pembuatan naskah audio visual, pembuatan audio visual, dan penyuntingan materi dan video, selanjutnya di masukan ke CD room.

Tahap implementasi dalam penelitian pengembangan ini meliputi validasi media audio visual dan uji coba terbatas. Validas audio visual merupakan tahap penilaian yang dilakukan ahli media. Tujuan dari tahap validasi untuk mengetahui kelayakan media audio visual yang akan dikembangkan sekaligus dijadikan dasar untuk melakukan perbaikan media. Tahap uji coba terbatas yaitu dengan menguji cobakan media audio visual kepada pengguna setelah dinyatakan valid oleh Ahli Media. Uji coba terbatas dilakukan pada dua orang dosen morfologi bahasa Indonesis Unismuh Makassar. Dilanjutkan dengan uji coba pembelajaran kepada 40 orang peserta didik. Tahap Evaluasi ini merupakan tahapan terakhir dalam proses pengembangan media audio visual yaitu melakukan proses hasil analisis data yang telah diperoleh pada saat implementasi. Respon penggunaan media audio visual morfologi bahasa Indonesia integrasi pendidikan budaya dan nilai karakter yang divalidasi dari dosen ahli media pendidikan Teknologi. Berdasarkan hasil validasi ahli media, media pembelajaran audio visual untuk pengajaran mata kuliah morfologi mendapat tanggapan positif dari validator dengan jumlah keseluruhan jawaban dalam seluruh item sebanyak 101 dari 105 nilai ideal yang ditetapkan. Persentase validitas media audio visual sebesar 96,19\% dengan kriteria "Sangat Valid", maka dinyatakan valid digunakan sebagai bahan ajar dan sumber belajar. Tahap uji coba terbatas yaitu, rata hasil angket respons guru dari segi aspek penyajian materi sebesar $96,25 \%$. Ini berarti guru memberikan respons sangat positif bahwa penyajian materi jelas. Aspek tampilan media sebesar 94,00\% menunjukkan guru memberikan respons sangat positif karena kemenarikan tampilan media audio visual yang dikembangkan. Aspek penggunaan media sebesar $86,66 \%$ menunjukkan guru memberikan respons positif karena media audio visual mudah untuk digunakan, mampu meningkatkan pemahaman peserta didik, mendorong kemandirian peserta didik dan meningkatkan motivasi peserta didik. Hasil persentase rata-rata total respons guru sebesar $92,30 \%$ dengan kriteria "Sangat Praktis" dan disimpulkan bahwa media audio visual morfologi bahasa Indonesia integrasi pendidikan budaya dan nilai karakter digunakan sebagai bahan ajar/sumber belajar pada prodi Pendidikan Bahasa dan Sastra Indonesia. Uji coba terbatas juga dilakukan pada 40 mahasiswa kelas IIA dan II B untuk mengetahui kepraktisan penggunaan media audio visual pengajaran morfologi bahasa Indonesia integrasi 


\begin{tabular}{|c|c|c|}
\hline & $\begin{array}{c}\text { Kredo } 4(2020) \\
\text { KREDO: Jurnal Ilmiah Bahasa dan Sastra } \\
\text { Terakreditasi Sinta } 4 \text { berdasarkan Keputusan Direktorat } \\
\text { Jenderal Penguatan Riset dan Pengembangan, } \\
\text { Kementerian Riset, Teknologi dan Pendidikan Tinggi } \\
\text { Republik Indonesia } \\
\text { Nomor: 23/E/KPT/2019. 08 Agustus 2019 } \\
\text { https://jurnal.umk.ac.id/index.php/kredo/index }\end{array}$ & $\begin{array}{l}\mathrm{KREDO} \\
\square= \\
\square= \\
\square= \\
\square=\end{array}$ \\
\hline
\end{tabular}

pendidikan budaya dan nilai karakter. Rata hasil angket respons mahasiswa dari segi aspek tampilan sebesar 94,25\% . Aspek penyajian materi sebesar $93,88 \%$ menunjukkan mahasiswa memberikan respons sangat positif karena penyajian materi media audio visual jelas. Aspek fungsi media media sebesar 90,25\% menunjukkan peserta didik memberikan respons positif karena media audio visual mampu memotivasi mahasiswa, mendorong keaktifan dan kemandirian mahasiswa serta memfasilitasi mahasiswa untuk belajar di mana saja, kapan saja. Hasil persentase rata-rata total respons peserta didik sebesar 93,46\% dengan kriteria "Sangat Praktis".

Jika memperhatikan temuan penelitian dan pengembangan ini, sangat relevan dengan temuan penelitian dan pengembangan yang dilakukan oleh Rukayah pada tahun 2018. Rukayah mengembangkan media pembelajaran membaca puisi yang basisnya media audio visual. Produk yang dikembnagkan melalui serangkaian uji coba dan validasi dari ahli dan praktisi. Produk dinyatakan layak dal dilakukan uji coba. Hasil uji coba pun dinyatakn bahwa media audiovisual yang dikembangkan layak untuk diimplementasikan di sekolah (Rukayah dkk.., 2018). Relevansi lain yang terlihat antara penelitian Rukayah dengan penelitian ini yaitu kesimpulan penelitian yang mebenarkan bahwa media audio visual efektif dan berpengaruh positif terhadap hasil belajar (Firdaus, 2016; Haryoko, 2012; Prasetia, 2016; Purwono, 2014; Rifai, 2018)

274 | Jurnal Kredo Vol. 4 No. 1 Oktober 2020

\section{SIMPULAN}

Berdasarkan hasil penelitian dan pembahasan terhadap pengembangan media audio visual dalam pengajaran morfologi bahasa Indonesia integrasi pendidikan budaya dan nilai karakter, maka disimpulan sebagai berikut:

Proses pengembangan pemanfaatan media audio visual morfologi bahasa Indonesia melalui tahap pengembangan ADDIE yaitu analysis, design, developmnet, implementation, and evaluation (Tegeh and Kirna, 2013). Tahap pertama pengembangan yaitu tahap analisis yang meliputi analisis kebutuhan mahasiswa, analisis kurikulum, analisis perangkat lunak dan perangkat keras. Tahap kedua analisis kebutuhan peserta didik meliputi pemikiran tentang produk bahan ajar yang akan dikembangkan. Mengidentifikasi produk yang sesuai dengan sasaran peserta didik, tujuan belajar, mengidentifikasi lingkungan belajar dan strategi penyampaian dalam pembelajaran. Tahap ketiga analisis kurikulum dilakukan dengan cara menyesuaikan rancangan pengembangan bahan ajar dengan kurikulum yang digunakan di Prodi Pendidikaan Bahasa dan Sastra Indonesia yaitu kurikulum 2013. Tahap keempat analisis perangkat lunak dan perangkat keras dilakukan dengan menentukan software dan hardware yang akan digunakan dalam pengembangan Media audio visual pengajaran morfologi bahasa Indonesia integrasi pendidikan budaya dan nilai karakter digunakan untuk pembuatan media audio visual morfologi Bahasa Indonesia ini adalah CD. Pada tahap desain/perancangan, peneliti merancang 


Kredo 4 (2020)
KREDO: Jurnal Ilmiah Bahasa dan Sastra
Terakreditasi Sinta 4 berdasarkan Keputusan Direktorat
Jenderal Penguatan Riset dan Pengembangan,
Kementerian Riset, Teknologi dan Pendidikan Tinggi
Republik Indonesia
Nomor: 23/E/KPT/2019. 08 Agustus 2019
https://jurnal.umk.ac.id/index.php/kredo/index

konsep produk baru di atas kertas. Rancangan ditulis untuk masing-masing unit pembelajaran. Petunjuk penerapan desain atau pembuatan produk ditulis secara rinci. Kegiatan yang dilakukan pada tahap perencanaan meliputi: perancangan materi, perancangan naskah audio visual, rancangan desain awal media audio visual, dan pembuatan instrumen kelayakan.

Development (tahap pengembangan) produk sesuai dengan rancangan yang sudah ditentukan sebelumnya untuk diproses menjadi audio visual pengajaran morfologi bahasa Indonesia meliputi: pembuatan naskah, tentukan objek, pembuatan audio visual menggunakan Kamera/HP, penyuntingan audio visual. Tahap implementasi dalam penelitian pengembangan ini meliputi validasi audio visual dan uji coba terbatas. Validasi audio visual merupakan tahap penilaian yang dilakukan ahli media. Tujuan dari tahap validasi untuk mengetahui kelayakan audio visual yang akan dikembangkan sekaligus dijadikan dasar untuk melakukan perbaikan audio visual. Tahap uji coba terbatas yaitu dengan mengujicobakanaudio visual kepada pengguna setelah dinyatakan valid oleh ahli media. Uji coba terbatas dilakukan pada dua orang dosen morfologi Bahasa Indonesia dilanjutkan dengan uji coba pembelajaran kepada 40 orang mahasiswa. Tahap evaluasi ini merupakan tahapan terakhir dalam proses pengembangan audio visual yaitu melakukan proses hasil analisis data yang telah diperoleh dan melakukan revisi tahap akhir berdasarkan komentar dan saran saat implementasi. Respon
Pengguna media audio visual morfologi Bahasa Indonesia.

Berdasarkan hasil validasi ahli media, audio visual mendapat tanggapan positif dari validator dengan jumlah keseluruhan jawaban dalam seluruh item sebanyak 101 dari 105 nilai ideal yang ditetapkan. Persentase validitas audio visual sebesar 96,19\% dengan kriteria "Sangat Valid" maka, E-Modul dinyatakan valid untuk digunakan sebagai bahan ajar.

Rata hasil angket respons guru dari segi aspek penyajian materi sebesar $90,25 \%$. Ini berarti guru memberikan respons sangat positif bahwa penyajian materi jelas. Aspek tampilan media sebesar $90,00 \%$ menunjukkan guru memberikan respons sangat positif karena kemenarikan tampilan E-Modul. Aspek penggunaan media sebesar $86,66 \%$ menunjukkan guru memberikan respons positif karena media audio visual mudah untuk digunakan, mampu meningkatkan pemahaman mahasiswa, mendorong kemandirian mahasiswa dan meningkatkan motivasi mahasiswa. Hasil persentase rata-rata total respons dosen sebesar 88,95\% dengan kriteria "Sangat Praktis" dan disimpulkan bahwa media audio visual morfologi bahasa Indonesia integrasi Pendidikan budaya dan nilai karakter sangat paraktis digunakan sebagai bahan ajar dan sumber belajar morfologi bahasa Indonesia pada Pendidikan Bahasa dan Sastra Indonesia di Semester II.

Rata hasil angket respons peserta didik dari segi aspek tampilan sebesar $88,95 \%$. Ini berarti peserta didik memberikan respon sangat positif bahwa tampilan audio visual menarik. Aspek penyajian materi sebesar 90,88\% 


Kredo 4 (2020)
KREDO: Jurnal Ilmiah Bahasa dan Sastra
Terakreditasi Sinta 4 berdasarkan Keputusan Direktorat
Jenderal Penguatan Riset dan Pengembangan,
Kementerian Riset, Teknologi dan Pendidikan Tinggi
Republik Indonesia
Nomor: 23/E/KPT/2019. 08 Agustus 2019
https://jurnal.umk.ac.id/index.php/kredo/index

menunjukkan peserta didik memberikan respons sangat positif karena penyajian materi audio visual jelas. Aspek fungsi media media sebesar 90,25\% menunjukkan peserta didik memberikan respons positif karena audio visual mampu memotivasi peserta didik, mendorong keaktifan dan kemandirian peserta didik serta memfasilitasi peserta didik untuk belajar di mana saja, kapan saja. Hasil persentase rata-rata total respons peserta didik sebesar $88,90 \%$ dengan kriteria "Sangat Praktis" dan disimpulkan bahwa audio visual morfologi bahasa Indonesia integrasi pendidikan budaya dan nilai karakter pada Prodi Pendidikan Bahasa dan Sastra Indonesia.

\section{DAFTAR PUSTAKA}

Anastasia, P., \& Sunahrowi, R. (2019). Ilmu Budaya Dari Strukturalisme Budaya Sampai Orientalisme Kontemporer. CV. Rizquna.

Barab, S. A., \& Luehmann, A. L. (2003). Building sustainable science curriculum: Acknowledging and accommodating local adaptation. Science Education, 87(4), 454-467.

Basaria, I. (2004). Morfologi Nomina Dalam Bahasa Pakpak Dairi.

Bashori, K. (2010). Menata ulang pendidikan karakter bangsa. Media Indonesia. com, diunduh pada tanggal, 3 .

Cronjé, J. (2006). Paradigms regained: Toward integrating objectivism and constructivism in instructional design and the learning sciences. Educational technology research and development, 54(4), 387-416.

Falahudin, I. (2014). Pemanfaatan media dalam pembelajaran. Jurnal Lingkar Widyaiswara, 1(4), 104-117.

Firdaus, F. (2016). Efektivitas penggunaan media audio-visual dalam pembelajaran Sains. SPEKTRA: Jurnal Kajian Pendidikan Sains, 2(01), 46-54.

Gobyah, I. K. (2003). Berpijak pada Kearifan Lokal. Bali Pos, 4.

Handri, M. (2012). Penerapan Pasal 31 Undang-undang Dasar 1945 Ayat 4 Dalam Undang-undang Nomor 20 Tahun 2003 Tentang Sistem Pendidikan Nasional Di Sulawesi Tengah Tahun 2012. Tadulako University.

Haryoko, S. (2012). Efektivitas pemanfaatan media audio-visual sebagai alternatif optimalisasi model pembelajaran. Jurnal Edukasi Elektro, 5(1).

276 | Jurnal Kredo

Vol. 4 No. 1 Oktober 2020 


\begin{tabular}{|c|c|} 
Kredo 4 (2020) \\
KREDO: Jurnal Ilmiah Bahasa dan Sastra \\
Terakreditasi Sinta 4 berdasarkan Keputusan Direktorat \\
Jenderal Penguatan Riset dan Pengembangan, \\
Kementerian Riset, Teknologi dan Pendidikan Tinggi \\
Republik Indonesia \\
Nomor: 23/E/KPT/2019. 08 Agustus 2019 \\
https://jurnal.umk.ac.id/index.php/kredo/index
\end{tabular}

Juwita, D. T., Cahyono, A., \& Jazuli, M. (2017). Nilai-Nilai Piil Pesenggiri pada Tari Melinting di Desa Wana Lampung Timur. Catharsis, 6(1), 82-90.

Khusniati, M. (2014). Model pembelajaran sains berbasis kearifan lokal dalam menumbuhkan karakter konservasi. Indonesian Journal of Conservation, 3(1).

Kraidy, M. M., \& Murphy, P. D. (2008). Shifting Geertz: Toward a theory of translocalism in global communication studies. Communication Theory, 18(3), $335-355$.

Mahnun, N. (2012). Media pembelajaran (kajian terhadap langkah-langkah pemilihan media dan implementasinya dalam pembelajaran). An-Nida', 37(1), 27-34.

Muhson, A. (2010). Pengembangan media pembelajaran berbasis teknologi informasi. Jurnal Pendidikan Akuntansi Indonesia, 8(2).

Muttaqin, A. (2012). Pendidikan Karakter di Sekolah Upaya Membangun Karakter Bangsa. Al Hikmah: Jurnal Studi Keislaman, 2(1), 3.

Patta Rapanna, S. E. (2016). Membumikan Kearifan Lokal Menuju Kemandirian Ekonomi (Vol. 1). Sah Media.

Pendidikan, B. S. N. (2006). Standar isi. Jakarta: BSNP. Pengertian Budaya, Unsur, Wujud \& Fungsi Menurut Para Ahli - serupa.id. (n.d.).

Prasetia, F. (2016). Pengaruh Media Audio Visual Terhadap Hasil Belajar Matematika. JKPM (Jurnal Kajian Pendidikan Matematika), 1(2), 257-266.

Purwono, J. (2014). Penggunaan media audio-visual pada mata pelajaran ilmu pengetahuan alam di Sekolah Menengah Pertama Negeri 1 Pacitan. Jurnal teknologi pendidikan dan pembelajaran, 2(2), 142050.

Putra, N. (2011). Reseacrh and DevelopmentReseacrh and Development, Penelitian dan Pengembangan Suatu Pengantar. PT. Raja Grafindo. Jakarta.

Ramlan, M. (1981). Sintaksis. Yogyakarta, UP Karyono 1987. Morfologi Suatu Tinjauan Deskriptif.

Rifai, M. H. (2018). Pengaruh Penggunaan Media Audio Visual Terhadap Pemahaman Konsep Mitigasi Bencana Pada Mahasiswa Pendidikan Geografi. Edudikara: Jurnal Pendidikan Dan Pembelajaran, 3(1), 62-69. 


Kredo 4 (2020)
KREDO: Jurnal Ilmiah Bahasa dan Sastra
Terakreditasi Sinta 4 berdasarkan Keputusan Direktorat
Jenderal Penguatan Riset dan Pengembangan,
Kementerian Riset, Teknologi dan Pendidikan Tinggi
Republik Indonesia
Nomor: 23/E/KPT/2019. 08 Agustus 2019
https://jurnal.umk.ac.id/index.php/kredo/index

Rukayah, R., Tolla, A., \& Ramly, R. (2018). The Development of Writing Poetry Teaching Materials Based on Audiovisual Media of Fifth Grade Elementary School in Bone Regency. Journal of Language Teaching and Research, 9(2), 358366.

Smith, J. A. (2004). Reflecting on the development of interpretative phenomenological analysis and its contribution to qualitative research in psychology. Qualitative research in psychology, 1(1), 39-54.

Suparno, D. (2015). Morfologi Bahasa Indonesia. UIN Press.

Susanti, S. (2016). Membangun Peradaban Bangsa Dengan Pendidikan Karakter. Istawa: Jurnal Pendidikan Islam, 1(2), 138-159.

Susilana, R., \& Riyana, C. (2008). Media pembelajaran: hakikat, pengembangan, pemanfaatan, dan penilaian. CV. Wacana Prima.

Tegeh, I. M., \& Kirna, I. M. (2013). Pengembangan Bahan ajar metode penelitian pendidikan dengan addie model. Jurnal Ika, 11(1).

Wringe, C. (2006). Moral education: Beyond the teaching of right and wrong (Vol. 14). Springer Science \& Business Media. 